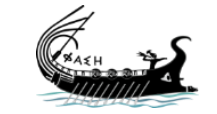

journal.phaselis.org
PHAS LLIS

Issue IV (2018)
Disiplinlerarası Akdeniz Araştırmaları Dergisi

Journal of Interdisciplinary Mediterranean Studies

\section{Phaselis Antik Kentinin Dönüşüm Sürecine Dair Yeni Bulgular}

New Assessments on Transformation Period of the Ancient City of Phaselis

Yalçın MERGEN

The entire contents of this journal, Phaselis: Journal of Interdisciplinary Mediterranean Studies, is open to users and it is an 'open access' journal. Users are able to read the full texts, to download, to copy, print and distribute without obtaining the permission of the editor and author(s). However, all references to the articles published in the e-journal Phaselis are to indicate through reference the source of the citation from this journal.

Phaselis: Journal of Interdisciplinary Mediterranean Studies is a peer-reviewed journal and the articles which have had their peer reviewing process completed will be published on the web-site (journal.phaselis.org) in the year of the journal's issue (e.g. Issue III: JanuaryDecember 2017). At the end of December 2016 the year's issue is completed and Volume IV: January-December 2018 will begin.

Responsibility for the articles published in this journal remains with the authors.

Citation Y. Mergen, "Phaselis Antik Kentinin Dönüşüm Sürecine Dair Yeni Bulgular". Phaselis IV (2018) 147-159. http://dx.doi.org/10.18367/Pha.18009

Received Date: 22.03.2018 | Acceptance Date: 18.04.2018

Online Publication Date: 03.05.2018

Phaselis Research Project

www.phaselis.org 


\title{
Phaselis Antik Kentinin Dönüşüm Sürecine Dair Yeni Bulgular
}

\author{
New Assessments on Transformation Period of the Ancient City of Phaselis
}

\author{
Yalçın MERGEN*
}

Öz: Phaselis Antik kentinde önceki yıllardan devamla, 2017 yılında gerçekleştirilen yüzey çalışmaları kentin Geç Antik Çağ ve Doğu Roma Dönemi'ne dair yeni veriler sunmuştur. Bu verilerin sağladığı katkılarla Phaselis'in kentsel oryantasyon ve yerleşim şemasının MS V. yüzyıl ve sonrası hakkında yeni değerlendirmeler mümkün olmaktadır. Özellikle Geç Antik Çağ'la beraber gerçekleşen değişimin sonucu olarak kent yaşamı ve planlamasında farklılıklar görülür. Phaselis kenti yerleşme planı özelinde bu değişimin kent dokusu ve oryantasyonuna yansımaları hakkında daha anlamlı ve açık yorumlar yapmak olanaklıdır.

Anahtar sözcükler: Phaselis, Geç Antik Çağ, Doğu Roma, Değişim, Dönüşüm

Abstract: Continuing from the previous year, surface studies in 2017 working season provided with new data on late antique and Byzantine periods in the ancient city of Phaselis. In the light of these data it is possible to make new assessments about urban orientation and site plan of Phaselis in $\mathrm{V}^{\text {th }}$ century A.D. and the later centuries. We can observe changes in urban texture and city planning occured in late antiquity due to cultural changes that occured in that period. About the reflections of this transition to the orientation and the texture of the late antique city, it is possible to make meaningful comments on the effects of the city with in the context of the settlement plan of the ancient city of Phaselis

Keywords: Phaselis, Late Antique, Byzantine, Change, Transformation

\section{Giriş}

Bilindiği gibi Phaselis antik kentinde sistematik yüzey araştırmaları 2012 yılından itibaren sürdürülmektedir. Bu çalışmalar çerçevesinde Phaselis'in kent merkezinde ve özellikle teritoryumunda kentin erken dönemlerine ilişkin birçok yeni veriye ulaşılmıştır ${ }^{1}$. 2014 yılından bu yana da kentin Geç Antikçağ, Doğu Roma ve Ortaçağ dönemlerine yönelik tematik çalışmalar araştırma programı kapsamında yoğun bir biçimde yerini almıştır. Söz konusu tarihten itibaren yapılan çalışmalar Phaselis kent merkezi ve teritoryumunun Geç Antikçağ ve Doğu Roma Dönemi açısından oldukça zengin bir repertuara sahip olduğu anlaşıımıştır. Özellikle kent merkezindeki tespitler, Phaselis'in MS V. yüzyıl ve sonrasındaki yaşamına dair net veriler ortaya koymaktadır². 2017 yılı itibariyle bu verilerin yorumu açısından daha geniş bir perspektife ulaşılmıştır.

Özellikle kentin akropolis'inde elde edilen ve geçmiş yıllardaki verilerle bütünleştirilen bazı sonuçlar, Phaselis'in fiziki yapısını sokak, insula, sivil ve dini mimari ilişkisi açısından çok daha anlaşılır hale getirmiştir. Antikçağın Doğu Roma uygarlığı ve kültürünün erken yüzyıllarını da kapsayan Geç Antikçağ’a dönüşüm sürecinin önemli bir tanığı da kent yaşantısındaki karak-

* Öğr. Gör. Dr., Dokuz Eylül Üniversitesi, Güzel Sanatlar Fakültesi Temel Eğitim Bölümü, ymergen68@gmail.com

1 Kentin erken dönemlerine ilişkin elde edilen verilerine ilişkin bkz. Arslan - Tüner Önen 2015a; 2015b; 2016a; 2016b.

2 Önceki yıllarda elde edilen sonuçlar için bkz. Mergen 2015; Mergen - Bilgin 2016; Mergen 2017. 
teristik değişiklikleridir. Yaşam biçimindeki değişim kentsel-kamusal mekân tasarımlarından, kentsel yapının en küçük birimlerinden olan konutlara kadar yansımıştır ${ }^{3}$. Phaselis'in bu dönüşümün önemli tanıklarından olduğu kentsel yapının kalıntılarına dayalı olarak söylenebilir.

2014 yılından bugüne kadar söz konusu dönemlere ilişkin yapılan çalışmalar sırasında arazi koşullarından kaynaklı olumsuzluklar, akropolis'te yer alan yapıların belgelenmesinde bazı eksikliklere neden olmuştur. Bu eksiklikler yapısal düzeyde olmakla birlikte yerleşim planının anlaşımasına da olumsuz yönde etki etmiştir. Bu nedenle 2017 yılı arazi çalışmaları, önceki yıllarda elde edilen verilerin tümlenebilmesi ve anlamlı sonuçlara ulaşabilmesi amacıyla öncelikli olarak Akropolis Tepesi'nde daha önce görülen ancak olumsuz arazi koşulları nedeniyle belgelenemeyen yapılarda gerçekleştirilmiştir. Özellikle yapı türlerinin tipolojik özelliklerinin anlaşılması ve buna dayalı olarak yapısal özelliklere dayalı tipolojik bir repertuar oluşturmanın başlangıına adım atmak hedeflenmiştir. Ayrıca söz konusu yapıların konumları itibari ile kent plan şemasının anlaşılmasına destek olması da amaçlanmıştır.

Kent içindeki çalışmaların Akropolis Tepesi'nde yoğunlaşmasının en önemli nedeni, 2014 yılından itibaren elde edilen veriler ışığında, kentin bu biriminde yüzeyde görülebilen kalıntıların tamamen Doğu Roma Dönemi'ne tarihleniyor olmasıdır. Akropolis Tepesi'nin bu özelliği Phaselis'in Doğu Roma Dönemi kentsel yerleşim stratejisi, planı, oryantasyonu ve kronolojisine ışık tutması dışında hem Lykia ve Anadolu hem de diğer coğrafyalarda yapılan çalışmalara sivil ve dini mimari tipolojisi, inşa teknikleri, dönemlere dair mimari üslupsal özellikler gibi konularda da açılımlar getirecek niteliktedir. Bu nedenlere dayalı olarak 2017 yılında da Phaselis akropolis'inde çalışmaya devam edilmiştir.

\section{Akropolis Çalışmaları}

Akropolis olarak tanımlanan birim Kentin yaklaşık doğusunda Güney ve Kuzey Liman olarak adlandırılan kent birimlerinin arasında kalan yarımadadır. Deniz seviyesinden $30 \mathrm{~m}$ rakıma sahip tepenin doğusu tamamen Akdeniz'e bakan yalı yarlar, batı kısmı ve kente bakan cephesi ise görece dik eğimli yamaçlarla çevrilidir (Fig. 1).

Akropolis'te yapılan yüzey belgeleme çalışmaları koordinat sistemine dayalı olarak üretilmiş olan 100 x 100 m ölçülerine sahip sektörler çerçevesinde sürdürülmüştür. 2017 yılında F-E XII, GF-E XIII, F-E XIV ve G XVI sektörleri bitki örtüsünün sıklığına rağmen taranmış bu sektörlerde tespit edilen yapılar belgelenmiştir (Fig. 1, 2, 3). 2017 yılı çalışmaları ile birlikte akropolis'te belgelenebilen yapıların plan şeması, konum, mekânsal ilişki ve sınırları gibi karakteristik özellikleri netlik kazanmaya başlamıştır. Aynı zamanda yerleşke şeması da anlaşılır düzeyde belirginleşmiştir. Bu nedenlere dayalı olarak özellikle kuruluş şema ve yerleşim alan sınırı tanımlı ya da bunlara dair fikir verebilen mekân toplulukları ayrı ayrı adlandırılmaya başlamıştır.

\section{FXII Sektörü}

Phaselis akropolis'inin batı yamacında ve FXII sektöründe yer alan tiyatronun cavea üst sınırında bulunan yapım teknikleri nedeniyle Doğu Roma Dönemi'ne ait olduğu düşünülen bir adet mekân topoğrafik kent planına işlenmiştir (Fig. 1, 2). Yüzeyde görülen duvar kalıntıları mekânın plan ve organik ilişki özelliklerini tanımlayacak yeterlikte değildir. Mekânlardan birisini doğuda sınırlayan duvarın 4, güneyde sınırlayan duvarın ise 5 metrelik kısmı günümüze ulaşabilmiştir.

3 Yüksek edebi kültürün görselleşmesi için bkz. Métraux 1999, 392, 397; kentsel kamusal alanların dönüşümü için bkz. Saradi 2006, 148-185; kentsel ekonomi, yönetimdeki dönüşümler için bkz. Whittow 1990; kentsel idea ve biçimsel dönüşümün bazı örnekleri için bkz. Zanini 2003, 196 - 223 


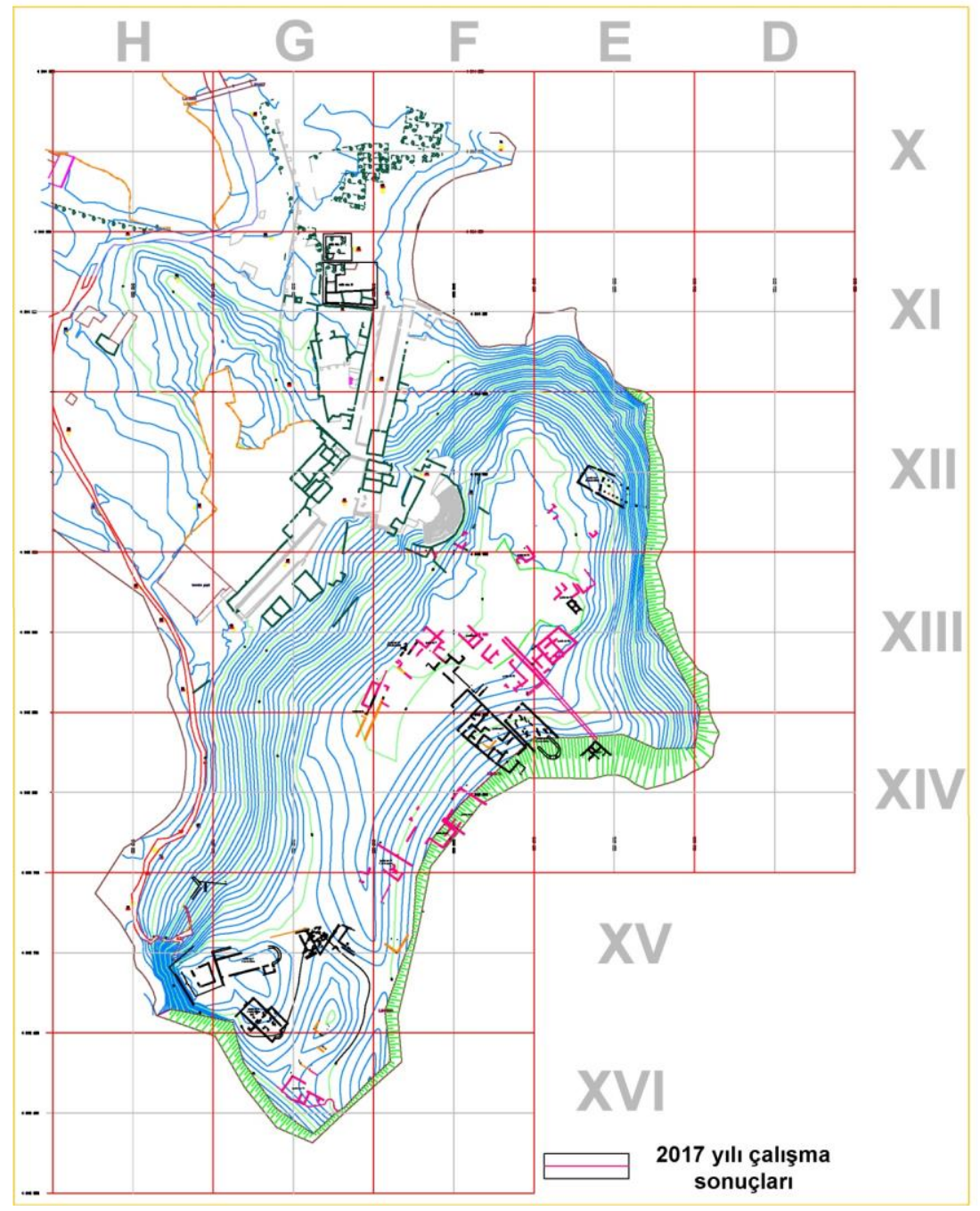

Fig. 1. Phaselis Akropolis'i Topoğrafik Yerleşim Planı ve 2017 Çalışma Sonuçları.

Mekânın doğu duvarında bir adet dörtgen planlı niş bulunmaktadır. Bu iki duvar birleşerek mekânın güneybatı köşesini oluşturmaktadır. Mekânların işlevleri yüzeydeki verilere dayalı olarak anlaşılabilir durumda değildir. Duvarlarda kullanılan inşa malzemesi moloz taş, bağlayıcı malzeme ise kireç harcıdır.

\section{EXII Sektörü}

Phaselis akropolis'inin kuzey bölümünü içeren bu sektör içinde önceki yıllarda belgelenen 2 numaralı kilise yer almaktadır (Fig. 1, 2). Akropolis'in bu bölümü özellikle bol miktardaki çam ağaçlarının döktüğü çam iğneleri ve yıkıntı molozunun tüm kalıntıları kaplaması nedeniyle yüzey çalışmalarında zengin veri elde etmenin mümkün olmadı̆̆ı bir alandır. Yüzeyde bu nedenlerden dolayı az miktarda duvar kalıntısı izlenebilmektedir. 2017 sezonunda bu birimde yüzeyde izlenebilen duvarlar da kent planına eklenmiştir (Fig. 1, 2). Muhtemel 4 farklı mekâna ait olduğu anlaşılan duvarlar küçük ve kısa birimler halinde izlendiğinden, sınırladıkları mekânların plan özellikleri ve işlevleri hakkında fikir ileri sürmek mümkün değildir.

\section{FXIII - EXIII Sektörleri}

2017 çalışma sezonunda FXIII sektöründe yapılan çalışmalar iki farklı amaca yöneliktir. Bunlardan 
ilki; Arazi koşulları nedeniyle ölçümleri yarım kalan bazı mekânların çalışmalarının tamamlanmasıdır. Bu nedenle GXIII, XIV sektör sınırlarında bulunan ve FXIII sektörüne de uzanan erken döneme ait anıtsal yapı çevresinde bu yapı ile bağlantılı geç dönem mekânları hem yeniden ölçülmüş, bir önceki sezonun sonuçları teyit edilmiş hem de yarım kalan bazı mekân çalışmaları tamamlanmıştır (Fig. 1, 3). İkinci amaç ise, daha önce belgelenen mekânlarla olası ilişkisi bulunan yeni birimleri topoğrafik kent planına eklemek ve bu alandaki yapı stoku açısından organik ilişkileri ortaya koyabilmektir.

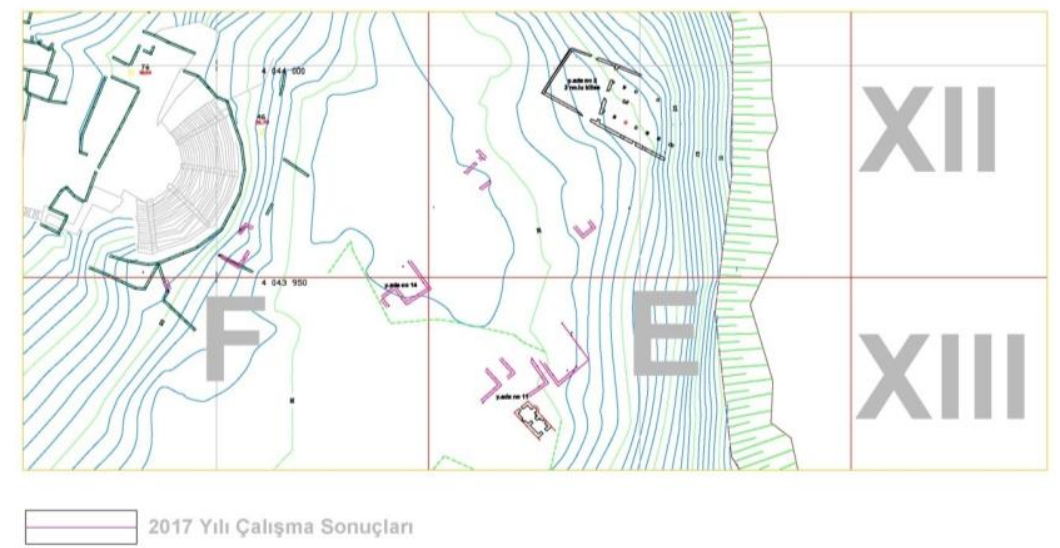

Fig. 2. Phaselis Akropolis Çalışmaları. F-E/XII - XIII Sektörleri.

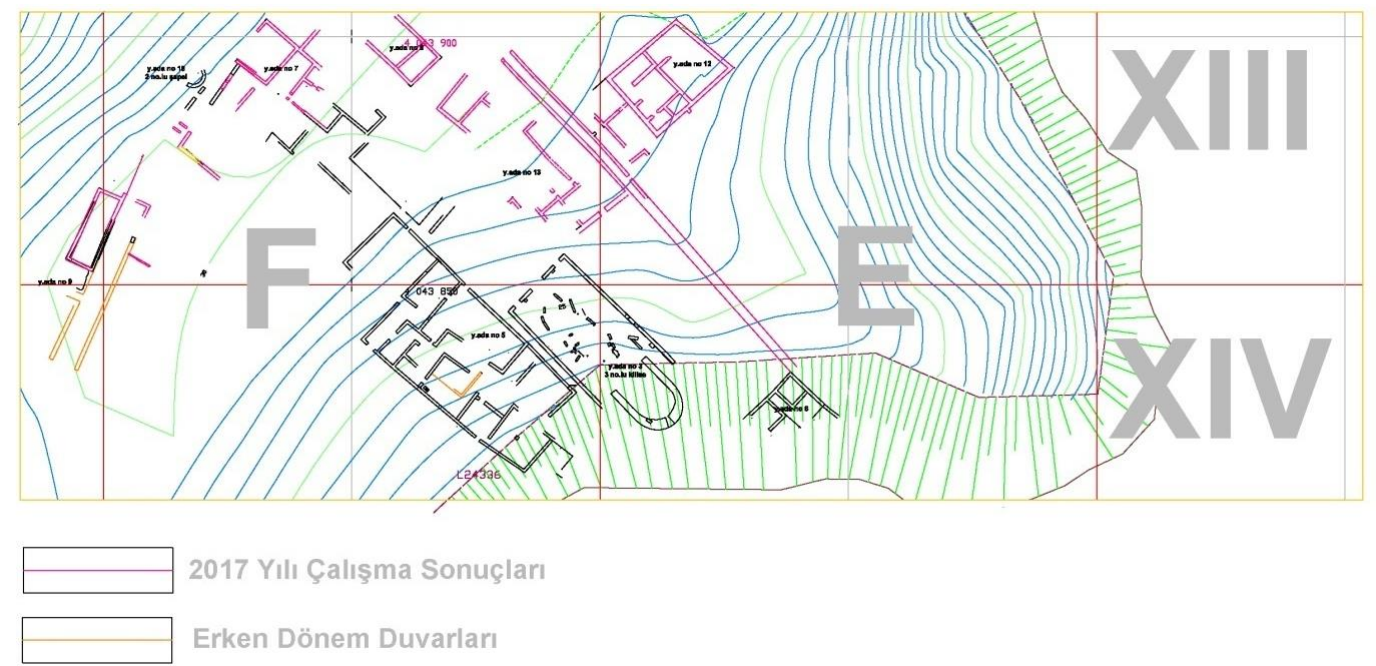

Fig. 3. Phaselis Akropolis Çalışmaları. F-E/XIII Sektörleri Detay.

2015 ve 2016 sezonlarında EXIII-FXIII ve XIV sektörlerinde yapılan çalışmalarla elde edilen sonuçlar FXIII sektöründe çalışmaların genişletilmesi gereğini doğurmuştur. Bunun nedeni söz konusu yıllarda ve sektörlerde yapılan çalışmalarla ortaya çıkan sonuçların akropolis yerleşim planının anlaşılmasına elverişli bir zemin hazırlamış olmasıdır. FXIII ve FXIV sektörlerinde tespit edilen yaklaşık doğu batı doğrultulu geçit, bu geçidin her iki yanında görülen yapı toplulukları ve 3 no.lu kilise kentin yerleşim planının yorumu açısından önemli ipuçları sunmuştur (Fig. 1, 3). Tümleşik bir plan yorumu için gerekli olan verilerin elde edilmesi, bu alana yakın sektörlerde bulunması muhtemel yapı topluluklarının da plana eklenmesi zorunluluğunu doğurmuştur. Bu nedenlere bağlı olarak akropolis'teki çalışmalar açısından FXIII ve EXIII sektörlerine öncelik verilmiştir. 


\section{FXIII Sektörü}

FXIII sektöründe 2016 yılındaki çalışmalar bu birimde düzenli yapılaşmanın varlığını ortaya koymuştur. Erken dönemlere ait bazı yapıların fiziki konumlarının ve şu anki verilere dayalı olarak en azından dış cephe duvarlarının geç dönemde de kullanıldığı anlaşımaktadır. Bu nedenle akropolis'teki geç dönem yerleşim planının erken dönem yerleşim planına uyumlaştııılığını düşünmek yanlış olmayacaktır ${ }^{4}$ Özellikle sektörün kuzeybatısına yakın kısmındaki 7 numaralı yapı adasında izlenebilen kesme taş bloklar üzerine yerleştirilmiş geç dönem yapı malzeme ve tekniği arz eden duvarların varlığı, erken dönem yapılarının yerleşim şemasının geç dönem yerleşiminde de sürdürüldüğünü göstermektedir. Akropolis'te bu duruma benzer uygulama örneklerine önceki yıllarda FXIV, GXV ve GXVI sektörlerinde de rastlanmıştır (Fig. 1, 3).

FXIII sektöründe 2017 çalışmaları ile elde edilen veriler, akropolis'in bu bölümünde oldukça düzenli ve sokaklarla bölünmüş bir yapılaşmanın varlığını işaret etmektedir (Fig. 1, 3). Sektörün kuzeybatısına yakın bölümde 2016 yılında belgelenen ve bir şapele ait olduğu anlaşılan apsis'i de kapsayan duvarlar bu birimde, birden fazla ve organizasyonu titizlikle düzenlenmiş yapı adaları olduğunu (y. ada no. 7 ve 18) göstermektedir (Fig. 5). Önceki yıllarda elde edilen verilere ek olarak tespit edilen ve belgelenen 14 adet farklı boyutlardaki mekân bu görüşü desteklemektedir. Bununla beraber yıkıntı molozu ve bitki örtüsü gibi engeller yapı adaları arasındaki ilişkiyi ve bu inorganik ve/veya organik ilişkiyi kurmayı sağlayan öğeleri tespit etmek açısından engeller teşkil etmektedir. Bu durum genel itibarı ile konutlara ait olduğu anlaşılan çok katı mekânların, özelde hangi işlevlerde kullanıldığını anlamayı da olumsuz yönde etkilemektedir.

Phaselis'in kentsel yapısının bu birimi ile ilgili bazı önemli sorular bulunmaktadır. Bunların başlıcaları sokak dizilimleri, yapı parsellerinin düzenleme prensipleri, parsellerin sokaklarla ve birbirleri ile olan ilişkileridir. FXIII sektörü bu soruların cevapları açısından bir başlangıç olarak kabul edilebilir veriler ortaya koysa da; özellikle yıkıntı molozu ve bitki örtüsü gibi nedenlerden dolayı cevaplar net olarak alınamamaktadır. Zira FXIV ve XIII sektörlerinde izlenen, kapı ve pencere açıklıklarının yönlendirilmesinden de destekle sokak olduğunu düşündüğümüz, 58 metre boyunca kuzeybatı-güneydoğu yönelişindeki y. Ada no. 19, 13, 5 ve 3 gibi farklı yapı adalarına ait duvarların sınırladığı bir geçit, FXIII sektörünün yaklaşık güneyinde genişleyerek belirsizleşmektedir (Fig. 1). Bu nedenle, duvarlar arasında yer alan 1.80 m genişliğindeki birimin sokak olup olmadığı konusunda soru işaretleri varlığını korumaktadır. Bu alanda yapılacak kazı çalışmalarının sonuçlar açısından destek sağlaması muhtemeldir.

\section{EXIII Sektörü}

Tam da bu bağlamda 2017 sezonunda çalışmaların EXIII sektörüne öncelik tanınarak geliştirilmesi mezkûr nedenleri geçerli kılmıştır. Zira EXIII sektöründe çalışma alanının nükleusunu oluşturan 3 no.lu kilisenin kuzeybatısında birçok veriye ulaşıımıştır. Bir konuta ait mekânlar topluluğu (y. ada no. 13), bu mekân topluluğun kuzeyinde bir sokak ve bu sokakla muhtemelen organik bağlantısı olan başka bir konuta ait olduğu varsayılabilecek mekânlar (y. ada no. 12) tespit edilmiştir (Fig. 1, 2). FXIII, EXIII ve EXIV sektörlerinde takip edilebilen sokağın konumu ve FXIII XIV sektörlerinde tespit edilen geçide paralel ve aynı yönde uzanmaktadır. Bu durum FXIII - XIV sektörlerinde izlenen geçidin de sokak olması ihtimalini güçlendiren bir bulgu olarak değerlendirilebilir. 2017 sezonunda tespit edilen bu sokak, "1 no.lu sokak" olarak adlandırımıştır. 1 no.lu

\footnotetext{
Lykia Bölgesi'nde kentsel plan ve organizasyonu etkileyen benzer uygulamalara dair bkz. Patara için bkz. Ruggieri 2009; Peschlow 2015. Andriake için bkz. Niewöhner 2012; Akyürek 2016. Olympos için bkz. Mergen 2011; Uçkan 2012; Öncü 2017; Uçkan, Öncü - Evcim 2017.
} 
sokağı sınırlayan duvarlar kuzeybatı-güneydoğu yönünde 48,52 metre boyunca izlenebilmektedir (Fig. 1, 2).

Yukarıda da değinildiği gibi, FXIII sektöründen başlayarak EXIII sektöründe de devam eden 1 no.lu sokağın kuzey doğusunda da oldukça düzenli plan özellikleri ve mekânsal bütünlük gösteren 12 numara ile adlandırılan bir yapı adası tespit edilmiştir (Fig. 1, 6). 12 numaralı yapı adasına ait duvar ve mekânlar, bitki örtüsü ve molozun izin verdiği oranda ölçülebilmiş ve topoğrafik kent planına aktarılmıştır. Buna göre 12 numaralı yapı adası kuzeydoğu - güneybatı aksında yaklaşık 30,89 m kuzeybatı-güneydoğu aksında ise 17,15 m boyutlarında bir alan üzerine yerleşmiştir (Fig. 2, 6). Yapının işlevi net olarak belirlenememekle birlikte, açıkça izlenen bir avluya sahip ve görülebilen tüm kapı açıkıklarının bu avluya yönelik olması, mekânlardan birisinin çok katılı kule tipi bir mekânın özelliklerini göstermesi; bu yapının işlevinin konut olduğunu düşündürmektedir. Ayrıca akropolis'te önceki yıllarda ve 2017 yılında yapılan çalışmalarla belgelenen ve konut olduğu açıkça anlaşılan yapılarla, plan ve mekânsal özellikler açısından gösterdiği benzerlikler de bu yapının bir konut olduğu düşüncesini güçlendirmektedir.

Yapının net olarak görülebilen 8 adet mekânı olması dışında en önemli özelliği, çok birimli ana mekânının güneybatı duvarlarının gene erken dönem duvarları kullanılarak ve bu duvarlar üzerine inşa edilmiş olmasıdır.

1 no.lu sokağın güneyinde ise, 13 numaralı yapı adasına ait duvarlar izlenebilmektedir. Görülebilen duvarlara dayalı olarak yapı adası, kuzeydoğu - güneybatı ve kuzeybatı - güneydoğu akslarında 34,71 x 38,78 metrelik bir alan üzerine yerleşmiştir (Fig. 1, 2, 7). Yıkıntı molozunun imkân verdiği ölçüde, yapı adasına ait birbirinden farklı 6 adet mekânsal birim belgelenebilmiştir (Fig. 7). Bu mekânların bazılarına geçişi sağlayan kapı açıkıkları yüzeyde görülebildiğinden, birbirleri ile organik bağlantıları olduğu anlaşılmaktadır (Fig. 7). Bununla beraber yıkıntı molozunun duvarların büyük kısmını kaplamasından ötürü, tümleşik plan özelliklerini tanımlamaya yeterli veri elde edilememiştir.

EXIII sektöründe kent planına eklenen diğer yeni mekânlar ise birbirleri ile olan ilişkileri tam olarak anlaşılamasa da 11 numara ile adlandırılan yapı adasıdır (Fig 1, 2). Önceki yıllarda bulunan ve belgelenen küçük hamamı da kapsayan bu yapı adası, 2017 yılında ilk defa görülebilen ve belgelenen bazı duvarlar ile genişlemiştir. Duvarların sınırladığı birimlerin işlevleri belirlenememekle beraber mekânsal yakınlıkları dolayısı ile şimdilik hamamla ilişkili oldukları söylenebilir. Hamamın kuzey ve kuzeybatısında görülen bu birimlerin üçünün yalnızca güneydoğu köşelerini teşkil eden duvarları görülebilmektedir. Kuzeydeki bir birim ise görece sağlam olarak günümüze ulaşmıştır ve ölçülebilen genişliği 8.30 metredir. Bu yapılarda da diğerlerinde olduğu gibi inşa malzemesi moloz taş, bağlayııı harç ise kireç harcıdır.

\section{FXIV Sektörü}

FXIV sektöründe yapılan çalışmalarla 3 adet yapı adası tespit edilmiş, belgelenmiş ve topoğrafik kent planına eklenmiştir. 15, 16 ve 17 numaralı yapı adaları sektörün güney bölümünde bulunmaktadır (Fig 1, 4). Bunlardan ikisi yani 15 ve 16 numaralı yapı adaları akropolis'in güneydoğusundaki yalıyarlar üzerindedir (Fig. 1). Olasılıkla bu yapılara ait bazı birimler zaman içinde gerçekleşen heyelan ve çöküntülerle Akdeniz'e karışmış gibi gözükmektedir. 17 numaralı yapı adası ise sektörün güneybatı köşesinde yer almaktadır (Fig. 1, 4).

15 ve 16 numaralı yapı adalarına ait duvarlar günümüze oldukça sağlam ulaşmışır. Her iki yapıda da bazı duvarların yükseklikleri 5 ila 6 metre arasında korunmuştur. Özellikle 15 numaralı yapı adasında bu durum açıkça gözlemlenmektedir. Yapının yerleştiği alanı güney kuzey ve 
batıda sınırlayan duvarlar oldukça iyi korunmuştur. Bu durum yapıların verili olmasını sağlamakla birlikte, çok kesif bitki örtüsü ile birleşince metrik ve fotoğrafik verilerin elde edilmesini neredeyse imkânsız hale getirmektedir. Ölçüm aletlerinin çalışmamasının dışında metre kullanmak dahi mümkün olamamıştır. Kent planına eklenen çizimler ise $0,60 \mathrm{~m}$ genişliğinde ve yer yer $6 \mathrm{~m}$ yükseklikteki duvarlar üzerinde hayati tehlikeye rağmen alınmıştır.

15 numaralı yapı adası elde edilebilen verilere bağı olarak kuzeydoğu-güneybatı, kuzeybatı-güneydoğu akslarında, 23,60 x 16,60 metrelik bir alanda izlenmektedir (Fig. 8). 16 numaralı yapı adasının ise gene elde edilebilen verilere dayalı olarak, aynı akslarda 18,35 x 11,45 metrelik bir alanı kaplamaktadır (Fig. 8). Yapıların yalı yarlara yakın birimlerinin göçüklere bağlı olarak tahrip olduğu varsayımına dayanarak, özellikle güneydoğu cephelerinde günümüze ulaşamamış başka mekânların da var olduğunu düşünmek olasıdır. Hem söz konusu durum hem de kuzeybatı cephelerindeki moloz yığını göz önünde bulundurulacak olursa, yapıların güney-

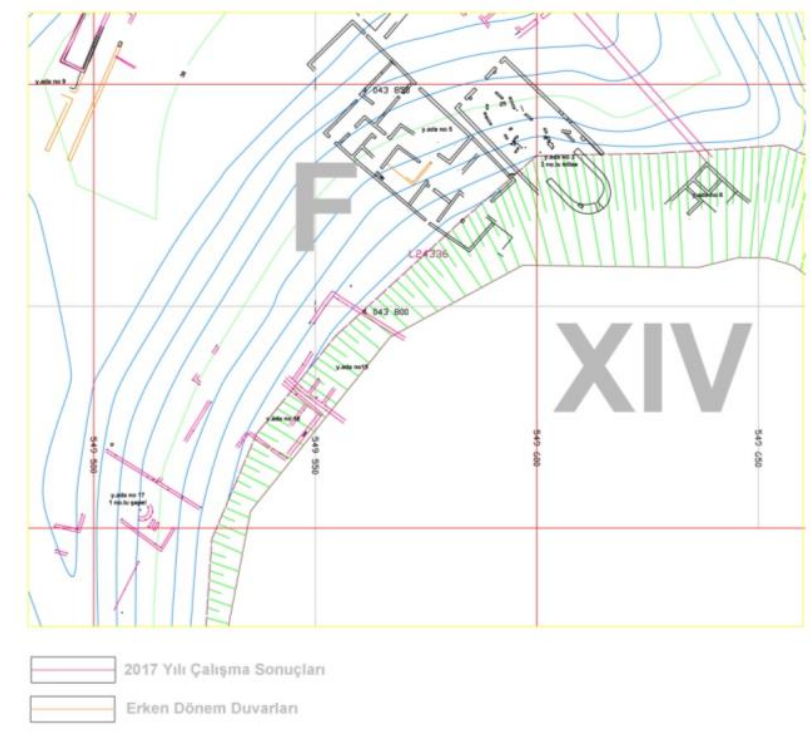

Fig. 4. Phaselis Akropolis Çalışmaları. F XIV Sektörü. doğu kuzeybatı aksında daha geniş bir alana yayıldığı düşünülebilir.

Korunagelen mekânlara dayalı olarak her iki adada bulunan yapıların çok birimli olduğu anlaşılmaktadır (Fig. 8). Bazı mekânlar Lykia'da yaygın olan kule tipi konutlarda izlenen özelliklere uygun biçimde çok katlıık arz etmektedir. Ayrıca gözlemlendiği kadarıyla her iki yapıdaki birimler bir avlu ile organik bağlantı halindedir (Fig. 8). Genel plan özelliklerine, mekân kuruluşu, organizasyonu ve ilişkilerine ayrıca da Phaselis'te tespit edilen örneklere dayalı olarak her iki yapı adasındaki bina kalıntılarının birer konuta ait olduğu anlaşılmaktadır.

Yapıların güneydoğu cephelerinde günümüze ulaşamamış başka mekânların bulunması varsayımından yola çıkarak yapı adalarının daha geniş bir alanda yayıldığını önermek yanlış olmayacaktır. Akropolis'te konut mimarisi açısından ve Doğu Roma Dönemi'nde bu derece geniş insula'ların tasarlanıp uygulanmış olması, konutların toplumsal hiyerarşinin üst katmanlarını oluşturan elitlerin bu alanda yerleştiğini işaret etmektedir.

16 numaralı yapı adasında gözlemlenen önemli bir unsur ise, yapıyı güneydoğuda sınırlandıran bir duvarın erken döneme ait olmasıdır (Fig. 8). Duvar, kuzeydoğu - güneybatı yönünde yaklaşık 11 metre boyunca uzanmakta ve yapının kuzeydoğu duvarı ile bir köşe oluşturmaktadır. Duvar malzemesi kesme taş bloklardan oluşmaktadır. İņ̧a tekniği ise isodomiktir. Bu durum Doğu Roma Dönemi'ne ait ve 16 numaralı ada sınırlarında bulunan konutun, erken dönem yapılarından, olasılıkla da kamusal ve prestijli biri üzerine, konumu ve planı dikkate alınarak inşa edildiğini kanıtlamaktadır.

15 ve 16 numaralı yapı adalarında bulunan binaların geç dönem evrelerinde kullanılan inşa malzemesi kaba yonu kesme taş, moloz taş, bağlayııı malzeme ise kireç harcıdır. Ayrıca duvarlarda görülen izlere dayalı olarak sıva ve boya tatbik edildiği anlaşımaktadır. 


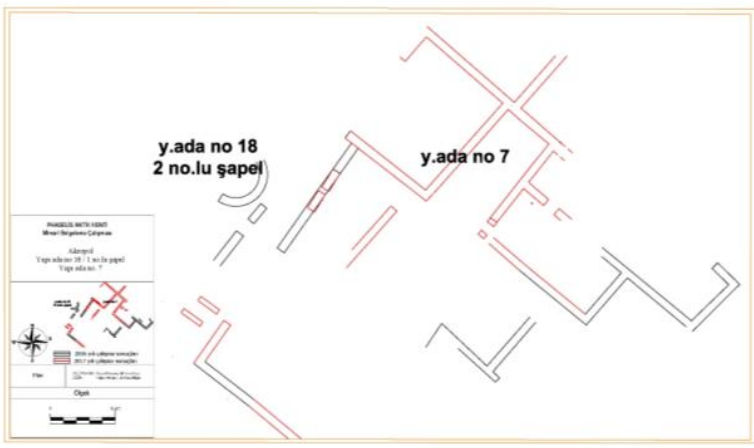

Fig. 5. Phaselis Akropolis'i 7 ve 18 Numaralı Yapı Adalarında Belgelenen Mimari Birimler.

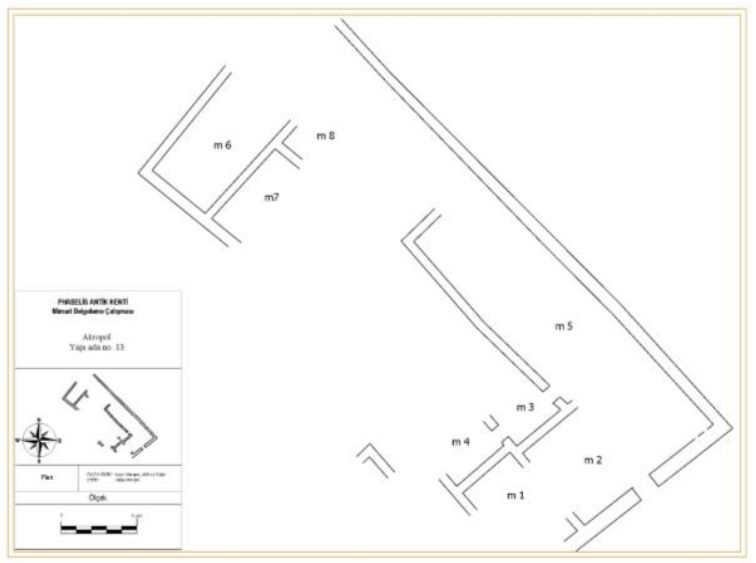

Fig. 7. Phaselis Akropolis'i 13 Numaralı Yapı Adasında Bulunan Konut.

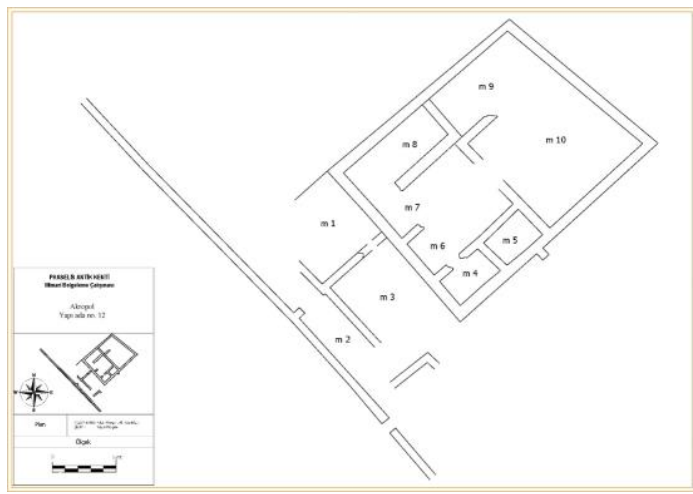

Fig. 6. Phaselis Akropolis'i 12 Numaralı Yapı Adasında Bulunan Konut.

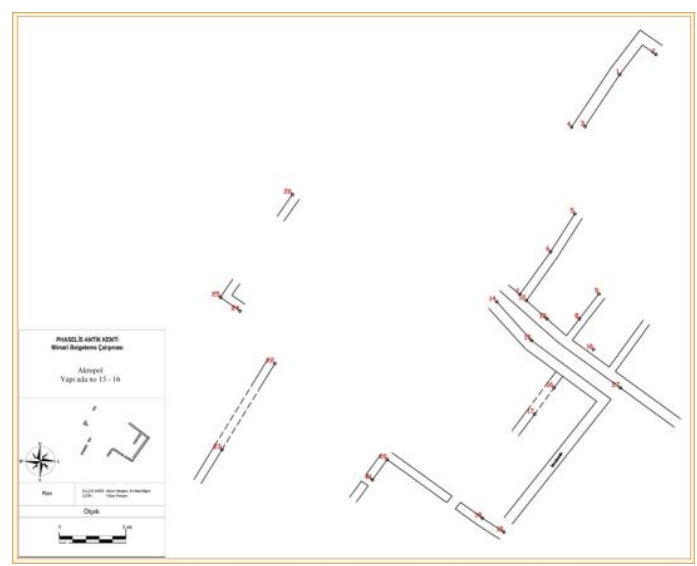

Fig. 8. Phaselis Akropolis'i 15 ve 16 Numaralı Yapı Adalarında Bulunan Konutlar ve Sokak.

Sektörün güneybatı köşesinde ise 17 numaralı yapı adası bulunmaktadır (Fig. 1, 4). 17 numaralı yapı adası Phaselis'in Hıristiyanlık dönemi mimarisine katkıda bulunan yeni bir şapeli içermektedir (Fig. 9). Kuzeybatı güneydoğu aksında yöneliş gösteren yapının sadece apsis'i günümüze ulaşabilmiştir (Fig. 9). Apsis boyutları nedeniyle yapının olasılıkla küçük ve tek mekânlı bir şapel olduğu düşünülmektedir. Var olması muhtemel duvarlar yıkıntı molozu altında kaldığından şapelin naos'unu sınırlayan duvarları izlenememektedir. Apsis'in doğusunda ve hemen önünde, alt kotta daha erken dönemlere ait bir sarnıç yer almaktadır (Fig. 9).

Bunların dışında şapelin kuzey ve güneyinde bazı duvarlar tespit edilmiştir. Kuzeyde yer alan duvar şapele paralel olarak güneydoğu-kuzeybatı doğrultusunda uzanmaktadır. 24,82 m izlenen bu duvar, kuzeybatıda ve kendisiyle aynı doğrultuda uzanan, kesme taş bloklarla inşa edilmiş daha erken tarihli bir duvarla birleşmektedir (Fig. 9). Duvarın yıkıntı nedeniyle kaybolduğu kuzeybatı ucunda ve duvarın kuzeydoğusunda bir sarnıç bulunmaktadır (Fig. 9). Ayrıca aynı duvarın güneydoğu kısmında bu duvarla köşe yapan bir başka duvarın 0,90 m uzunluğunda bir bölümü izlenmektedir. Bunların dışında bir veri olmadığından duvarların sınırladığı bu mekânın planı ve işlevi konusunda şimdilik bilgi vermek mümkün değildir. Bununla beraber güneydoğu bölümde görülen köşeden başlayarak kuzeydoğu-güneybatı doğrultusunda başlangıç yapan duvarın aksında ve 13,84 m mesafede bir başka duvarın uzandığı gözlemlenmiştir.

Şapelin güneyinde yer alan duvar ise güneydoğu-kuzeybatı doğrultusunda ve şapele paralel uzanmakla birlikte güneydoğuda, kuzeydoğu-güneybatı doğrultusundaki bir duvarla birleşerek 
köşe yapmaktadır (Fig. 9). Bu iki duvar hem şapelin hem de şapelin mülki alanında olduğu anlaşılan ve apsisin önünde yer alan sarnıın bulunduğu mahalli çevrelemektedir (Fig. 9).

17 numaralı yapı adasına yakın bir bölümde ancak F XIV sektörü sınırlarında ve bu sektörün kuzeybatı köşesinde bir adet teras duvarı tespit edilmiş ve topoğrafik plana eklenmiştir. Duvar güneybatı-kuzeydoğu yönelimli, 12 m uzunluğunda ve yer yer 2 metrenin üzerinde yüksekliğe sahiptir (Fig. 9). Teras duvarının hemen önünde ve alt teras zemininde iki adet sarnıç bulunmaktadır. Duvarın yönelişine dayalı olarak akropolis'in bu biriminin güneybatı -kuzeydoğu doğrultusunda uzanan iki

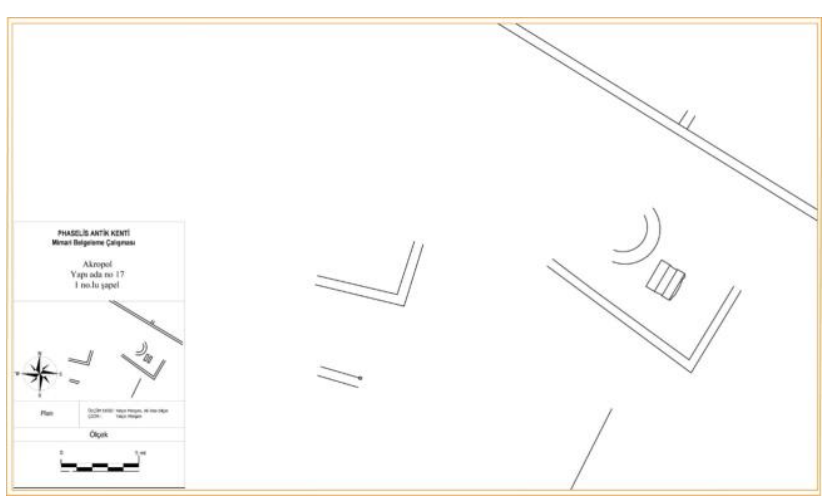

Fig. 9. Phaselis Akropolis'i 17 Numaralı Yapı Adasında Bulunan Mimari Kalıntılar ve Şapele Ait Apsis. basamaklı bir terasa sahip olduğu anlaşılmaktadır. Terasların yapılış amacı anlaşılamamıştır.

\section{GXVI Sektörü}

Bu sektörde 2017 yılı çalışmaları sırasında konut olduğu anlaşılan bir mekân kompleksi tespit edilmiş ve belgelenmiştir. Yapı ada no. 10 olarak adlandırılan mekân topluluğunda 5 farklı birim bulunmaktadır (Fig. 1). Söz konusu yapı adası Phaselis akropolisinin en kuzey ucunda ve yalıyar üzerinde konumlanmaktadır. Benzer konumdaki diğer yapı adalarında olduğu gibi, bu yapı adasında da bazı mekânların Akdeniz'e doğru çökerek kaybolduğu anlaşılmaktadır.

\section{Değerlendirme}

Phaselis akropolis'inde 2017 yılında yapılan çalışmalar, akropolis'teki yerleşim birimine yönelik daha anlaşılır sonuçlara ulaşılmasına olanak sağlamıştır. Söz konusu sonuçlar önceki yılların verileri ile birlikte desteklenerek şimdilik iki ana başlık altında derlenebilir. Bunlardan ilki Phaselis akropolis'indeki yerleşimin geneline dair planlama stratejisi, oryantasyonu ve kronolojisine yöneliktir. İkincisi, yerleşim planı özelliklerinin oluşmasına katkı sağlayan mimari türleri, bu türlerin tipolojisi ve konumlanışlarıdır. Bu başlıklar altında değerlendirildiğinde Phaselis akropolisi'nde günümüze ulaşan yerleşim yüzey çalışmalarıyla elde edilebilen bulgulara dayalı olarak Doğu Roma Dönemi açısından verilidir. Özellikle akropolis'te tespit elden yapı türleri arasında yer alan ve önceki yıllarda belgelenen dini mimari örnekleri tarihlendirme olanakları sağlamaktadır. Plan ve malzeme teknik özellikleri nedeniyle dini mimari örnekleri ve bu yapılarda elde edilen mimari plastik, anıtsal mimari plastik bulgular V. yüzyıl ile VII. yüzyıl arasına tarihlenmektedir ${ }^{5}$. Yüzey çalışmalarının sınırlılığı çerçevesinde akropolis'teki yerleşim biriminin VII. yüzyıl sonrasında ait bir veriye şimdilik ulaşılamamıştır. Bu tarihlendirme aralığı Lykia Bölgesi'nin kıyı kentleri için neredeyse ortak bir durumdur ve nedeni bilindiği gibi Arap akınlarıdır ${ }^{6}$. Arapların bölgedeki varlığı IX.

5 Phaselis akropolis'inde ve aşağı kentte bulunan Doğu Roma Dönemi yapılarının tarihlendirme önerileri için bkz. Schäfer 1981, 95-98; Bayburtluoğlu 1983, 185; 1985, 376-384, res. 13; 2004, 90-91; Mergen 2015, 281-285; Mergen-Bilgin 2016, 124-128.

6 Lykia ve Phaselis açısından Arap akınlarına ilişkin en etkili ve önemli olay; 655 yılı yazının başında, Fenike körfezinde ve olasılıkla da Gelidonya Burnu'na doğru bir mevkide başlayıp, Doğu Roma donanmasının kesin mağlûbiyeti ile sonuçlanan 'Mastlar Savaşıdır'. Theophanes, Muviye'nin büyük bir savaş filosuna Fenike'nin Tripolis Limanı'ndan hareket etmesini emrettiğini bildirmektedir. Muaviye Tripolis'ten hareket eden filonun komutanlığına Abu'l Awar'ı atamıştır (Theophanes 1982, 45). Hourani de (Hourani 1995, 58), Finike Körfezi'nde cereyan eden savaşta Arap 
yüzyılın ortalarına kadar zayıflayarak da olsa devamlılık göstermektedir. Ayrıca Arap akınları öncesinde imparatorluk başkentinin Lykia Bölgesi'yle yakından ilgilediği ve bazı inşa faaliyetlerinde bulunduğu bilinmektedir ${ }^{8}$. Bu veriler ışığında Phaselis akropolis'inde yer alan yerleşim birimi, antikçağ yerleşiminin birimleri kullanılarak, olasılıkla ve hipotetik olarak VI. yüzyılın hemen öncesinde gerçekleşen bir deprem akabinde yeniden imar edildiğini, VI. ila VII. yüzyıllar arasına tarihlenen ve günümüzde izlenen yerleşim biriminin karakteristik özelliklerini bu olaylara dayalı olarak kazandığını düşünmek mümkündür.

Kentin bu biriminde görülen yapı adalarının konumlanışı ile yapı adalarını birbirinden ayıran aynı zamanda da aralarındaki ulaşımı sağlayan ve eldeki kısıtlı veriler çerçevesinde sokak olduğu öngörülen düzenlemelerin; hem antikçağ düzenlemelerine sadık kaldığı aynı zamanda da alanın fiziki yapısına uyumlaştırıldığı anlaşılmaktadır. Buradan yola çıkarak söz konusu tarihler arasındaki yerleşimin, antikçağ yerleşiminin planlama stratejisini benimseyerek sürdürdüğg̈, akropolis'in fiziki özelliklerinin belirlediği şartlara uyumlu düzenlendiği, yapıların tipolojik açıdan da kendi döneminin özelliklerini eskisinin yerine ikame ettiğini düşünmek yanlış olmayacaktır.

Akropolis'te Doğu Roma Dönemi'ne tarihlenen yapı türleri şimdilik dini ve konut mimari örnekleridir. Phaselis'in dini mimari tipolojisi Erken Doğu Roma Dönemi'ne uygun örnekler sergilemektedir ${ }^{9}$. Aralarında özgün örnekler bulunmakla beraber, kullanılan plan şeması Helenistik bazilikal plan şeması ve bu plan şemasının çeşitleridir.

Phaselis kent merkezinde Doğu Roma Dönemi'ne ilişkin çalışmaların akropolis'te yoğunlaşmasının en temel nedeni, akropolis'in kent merkezine göre çok daha yoğun biçimde iskân edildiğinin saptanmış olmasıdır. Akropolis sivil yerleşimin konumlandığı bir birimdir ve konutların bulunduğu alandır. Yoğun yapılaşmanın nedeni bu duruma dayalı olarak açıklanabilir. Şu ana kadar elde edilen bulgular konutlara dair tipolojik yapısal özellikleri açıklayacak sonuç be-

donanmasının Abu'l Awar tarafından kumanda edildiğini belirtmektedir. Awar aynı zamanda Suriye Filosu'nun komutanı olarak zikredilir. Ancak Hitti'nin eserinde Fenike Körfezi'ne gelen Suriye donanmasına Busr ibn abi Artah'ın Komuta ettiği belirtilmektedir (Hitti 2004, 427). Theophanes Abu'l Awar'ın komutasında Lykia'ya gelen donanmanın Phoenix (Finike) sahilinde Roma donanması ile 655 yılında girdiği savaşı şu şekilde aktarmaktadır.

"Abu'l Awar imparator Konstans ve O’nun Roma deniz gücüne karşı Lykia'daki Phoiniks'te savaştığı yere geldi.......Imparator, Selanik'te gördügü rüyaya rağmen denizde gerçekleşebilecek bir karşılaşmaya hazırlıklı değildi. Iki güç savaşa dâhil olduğunda, Romalılar bozguna uğratıldı ve denize Romalı kanı karıştı. Imparator kendi elbiselerini başkasına giydirdi. Bukinator'un oğullarından birisi beklenmedik bir şekilde kraliyet gemisine atladı ve imparatoru başka bir gemiye geçirdi ve korudu. Imparatorluk gemisinde kalan seçkin dostu ise imparator için canını feda etti.... Tüm adamlarını geriye çeken imparator Konstantinopolis'e doğru yelken açtı" (Theophanes 1982, 45).

Muaviye'nin 672 yılında yeni bir deniz gücünü Anadolu’ya gönderdiğini ve bu gücün kumandanlarından Qais'in kışı Kilikia ve Lykia'da geçirdiği bilinmektedir. Bu tarihte Lykia'daki bazı liman kentlerinin saldırıya uğradığı gene Theophanes tarafından aktarılmaktadır (Theophanes 1982, 52).

7 Theophanes'ten Arapların 807'ye kadar Lykia'da varlıklarını hissettirdiklerini anlamaktayız. Bunun dışında IX. yüzyılda Kibyrrhaioton strategos'u olarak görev yaptığı dönemde Ioannes Ekhimos adını taşıyan ve daha sonra Genç Antonius ismini alan azizin hayatına dair yazılan anonim bir eserden 823 ile 825 yıllarında Antalya'nın Araplar tarafından bir kez daha saldırıya uğradığını öğrenmekteyiz (Pryor 2006; 307-308). Bu sıcak karşılaşmaların dışında Arap varlı̆ıının Lykia Bölgesi ve Kibyrrhaioton thema'sındaki son belirtileri, Doğu Roma donanmasının Gelidonya Körfezi'nde fırtınanın da yardımıyla Arap donanmasına karşı 842 yılında kazandığı zafer ve Basil Heksamilites'in 956 yılında Tarsus donanmasını Lykia'dan geri çekilmeye zorladığı harekâttır (Pryor 2006, 385). Nikephoros'un düzenlediği akınlar Arap hâkimiyetini yaklaşık üç yüzyıl sonra kırmıştır. 965 yılında Kıbrıs'ın ve Antakya'nın, 968 yılında ise Halep'in geri alınması uzun bir aradan sonra istikrarı yeniden sağlamıştır (Gregory 2005; 240).

8529 depremi ardından lustinianus'un Andriake'de gerçekleştirdiği yapı faaliyetleri (Akyürek 2016) başkentin bu tarihlerde Lykia Bölgesi'ndeki varlığına işaret etmektedir. Andriake dışında başka bir kentte de bu tür ve direkt imparator ya da başkentle ilgili bir faaliyete dair belgeye ulaşılamamışsa da bu faaliyetlerin Andriake ile sınırlı kalmadığı, Patara ve Olympos gibi mamur kentlerdeki anıtsal yapıların varlığına dayalı olarak öngörülebilir.

9 Schäfer 1981, 95-98; Mergen 2015, 281-285; Mergen-Bilgin 2016, 124-128. 
lirleyecek bir değerlendirmeyi olanaklı kılacak yeterlilikte değildir. Bununla beraber üç yapı adasında bulunan ve plan özellikleri açısından verili üç konut değerlendirme açısından bir başlangıç oluşturmaktadır.

Akropolis'te 1, 5, 10 ve 12 numaralı yapı adalarında bulunan söz konusu üç konut, şimdilik görece detaylı mekânsal organizasyon anlayışı dolayısı ile de plan şemaları hakkında fikir vermektedir. Yapıların ortak özelliği avlulu ve çok katlı mekân düzenlemeleridir. Bir ya da birden fazla avlulu konut plan tipinin Akdeniz' in hem Roma hem de Doğu Roma dönemleri için yaygın bir özellik olduğunu söylemek mümkündür ${ }^{10}$. Söz konusu üç konutta bu tipolojiye uygun biçimde ve tek avlu ile organik bağlantı halindeki muhtelif mekanların dizilimi ile düzenlenmiştir. Konutların sokak - avlu - iç mekân ilişkisi, Galor'un aktardığı Yeivin'e ait avlunun belirlediği konut tipolojisinin birinci tipine uygun örnekler teşkil etmektedir ${ }^{11}$.

Gelecek yıllarda yapılması planlanan arkeolojik kazılarla bu değerlendirmede ele alınan verilerin çeşitlilik kazanacağı kuşkusuzdur.

10 Doğu Roma Dönemi konut mimarisi plan özelliklerini konu edinene çalışmalar sınırlı olmakla temel ilkeler konusunda fikir vermektedir. Akdeniz ve çevresindeki Doğu Roma Dönemi konut mimarisi açısından plan tipleri ve gelişim şeması için bkz. Galor 2003; Binder 2009; Hirschfeld 1995. Avlunun plan şeması üzerine etkileri için bkz. Hirschfeld 1995; Galor 2003. Lykia Bölgesi, Doğu Roma Dönemi konut mimarisinin özellikleri için bkz. Harisson 1979; Harisson 1979a; 2001. Bölgesel ve dönemsel tematik bir çalışma olarak Kilikia, Doğu Roma Dönemi konut mimarisinin özellikleri için bkz. Eichner 2011. Hellas orta ve geç dönem konut mimarisi özellikleri için bkz. Bouras 1974, 1983, Sigalos 2003. Pergamon Doğu Roma Dönemi konut mimarisi özellikleri için bkz. Rheidt 1990.

11 Galor'un (2003) Yeivin'den aktardığı tipolojik gruplandırma arasında avlunun belirleyici olduğu bir grup da bulunmaktadır. Yeivin sokak - avlu - oda ilişkisi açısından konutları; 1 - Sokaktan iç mekânlara direkt girişe sahip yan ya da arka avlulu tip, 2 - Sokaktan direkt avluya girişin sağlandığı ve avlu vasıtasıyla iç mekanlara ulaşıldığı tip ve 3 iç avlu çevresinde organize olmuş mekanlara sahip tip olarak üç başlıkta değerlendirmektedir. 
Akyürek 2016

Arslan - Tüner Önen 2015a

Arslan - Tüner Önen 2015b

Arslan - Tüner Önen 2016a

Arslan - Tüner Önen 2016b

Bayburtluoğlu 1983

Bayburtluoğlu 1984

Bayburtluoğlu 1985

Binder 2009

Bouras 1974

Bouras 1983

Eichner 2011

Galor 2003

Gregory 2005

Harisson 1979

Harisson 1979a

Harrison 2001

Hirschfeld 1995

Hitti 2004

Hourani - Carswell 1995

Mergen 2011

Mergen 2015

Mergen, Bilgin 2016

Mergen 2017

\section{BİBLIYOGRAFYA}

T. E. Akyürek, "Andriake: The Port of Myra in Late Antiquity". Trade in Byzantium, Papers From The Third International Sevgi Gönül Byzantine Studies Symposium. Eds. P. Magdalino - N. Necipoğlu, İstanbul (2016) 465-487.

M. Arslan - N. Tüner Önen, "Phaselis ve Teritoryumu Yüzey Araştırması 2014", Anmed 13 (2015) 198-2017.

M. Arslan - N. Tüner Önen, "2014 Yılı Phaselis Antik Kenti ve Teritoryumu Yüzey Araştırması”. AST 33/2 (2015) 69-80.

M. Arslan - N. Tüner Önen, "Phaselis ve Teritoryumu Yüzey Araştırması 2015". Anmed 14 (2016) 236-246.

M. Arslan - N. Tüner Önen, "2015 Yılı Phaselis Antik Kenti ve Teritoryumu Yüzey Araştırması”. AST 34/1 (2016) 355-368.

C. Bayburtluoğlu, "1982 Phaselis Kazısı Raporu". KST V (1983) 181-189.

C. Bayburtluoğlu, "1983 Phaselis Kazısı Raporu". KST VI (1984) 301-312.

C.Bayburtluoğlu, "Phaselis Kazısı Raporu". KST VII (1985) 373-386.

E. Binder, Wohnhaus-Architektur in Byzanz - eine Bestandsaufnahme Verfasserin. Yayınlanmamış Doktora Tezi Universität Wien Wien (2009).

Ch. Bouras, "Houses and settlements in Byzantine Greece". Ekistics 38/228 (1974) 336-344, Cities of the Past Athens Center of Ekistics.

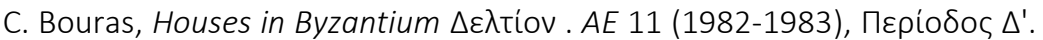

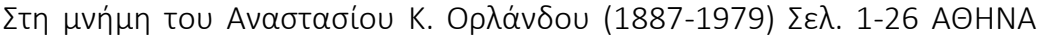
1983.

I. Eichner, Frühbyzantinische Wohnhäuser in Kilikien: baugeschichtliche Untersuchung zu den Wohnformen in der Region um Seleukeia am Kalykadnos. Ernst Wasmuth Verlag - Tübingen (2011).

K. Galor, "Domestic Architecture in Roman and Byzantine Galilee and Golan". Near Eastern Archaeology 66 1/2. House and Home in the Southern Levant. The American Schools of Oriental Research (2003) 44 - 57.

T. E. Gregory, A History of Byzantium. Blackwell Publishing 2005

M. Harisson, "Nouvelles découvertes romaines tardives et paléobyzantines en Lycie". CRAI (1979) 222-239.

M. Harisson, "An early Byzantine Town at Arif in Lycia". Yayla II (1979) 1317.

R. M. Harrison, Mountain and Plain: From the Lycian Coast to the Phrygian Plateau in the Late Roman and Early Byzantine Period. Ann Arbor: University of Michigan Press (2001).

Y. Hirschfeld, The Palestinian Dwelling in the Roman Byzantine Period. Jerusalem - Franciscan (1995).

P. K. Hitti, History of Syria: Including Lebanon and Palestine. Georgias Press (2004).

G. Hourani, Arab Seafaring in the Indian Ocean in Ancient and Early Medieval Times. Princeton University Press (1995).

Y. Mergen, Olympos Antik Kenti'nin Orta Çağ Dönemi Dokusu ve Likya Bölgesi Açısından Önemi. Yayımlanmamış Doktora Tezi, Ege Üniversitesi, İzmir (2011).

Y. Mergen, "2014 Yılı Çalışmaları Işı̆̆ında Phaselis Antik Kenti'nin Geç Antik ve Ortaçağ Mimarisi ile Kentsel Yapısı". Phaselis I (2015) 273-285. DOI: 10.18367/Pha.15014

Y. Mergen - A. R. Bilgin, "2015 Yılı Çalışmaları Kapsamında Phaselis Antik Kenti Akropolündeki Doğu Roma Yerleşimine Ait İzler". Phaselis // (2016) DOI: 10.18367/Pha.16007

Y. Mergen, "Phaselis 2016 Yılı Çalışmaları Işığında Akropolis Özelinde Doğu Roma Dönemi Kent Planı ve Mimarisi Üzerine Ön Değerlendirmeler". 
Métraux 1999

Niewöhner 2012

Öncü 2017

Peschlow 2015

Pryor - Jeffreys 2006

Rheidt 1990

Ruggieri 2009

Schäfer 1981

Sigalos 2003

Theophanes 1982

Uçkan 2012

Uçkan et al. 2017

Whittow 1990

Zanini 2003
Phaselis III (2017) 163-173. DOI: 10.18367/Pha.17010

G. P. R. Métraux, "Ancient Housing: 'Oikos' and 'Domus'". Greece and Rome The Journal of the Society of Architectural Historians 58/3 Architectural History (1999) 392 - 405.

P. Niewöhner, "Andriake in byzantinischer Zeit". Eds. M. Seyer, 40 Years of Excavations at Limyra. Akten des internationalen Symposions Wien, Wien 3.-5. Dezember 2009 (2012) 223-240.

E. Öncü, "Olympos Hellenistik ve Roma Dönemi Araştırmaları: Köprü, Köprü Caddesi ve Kent Surları". Eds. B. Yelda Olcay Uçkan, Olympos 1 2000 - 2014 Araştırma Sonuçları. AKMED - Antalya (2017) 31 - 48.

U. Peschlow, "The Cemetery Church at the Tepecik Necropolis of Patara. A Preliminary Report". Eds. Havva İşkan - Fahri Işık, PATARA VII. 1 Ege Yayınları - İstanbul (2015) 463 - 475.

John H. Pryor - M. Elizabeth Jeffreys, The Age of the $\triangle P O M \Omega N$ : The Byzantine Navy ca. 500-1204. Brill Academic Publishers, Boston (2006)

K. Rheidt, "Byzantinische Wohnhauser des 11. bis 14. Jahrhunderts in Pergamon". Dumbarton Oaks Papers 44 (1990) 195-204.

V. Ruggieri, "Patara: due casi di architettura bizantina e la continuità urbana". Orientalia Christiana Periodica vol. 75 (2009) 319-341

J. Schäfer, Phaselis. Beiträge zur Topographie und Geschichte der Stadt und ihrer Häfen.Tübingen 1981.

L. Sigalos, "Housing People in Medieval Greece". International Journal of Historical Archaeology 7/3 September 2003 (2003) 195 - 22.

Theophanes, The Chronicle of Theophanes: an English Transletion of anni mundi 6095-6305 (602-813). Ed. and Trans. Harry Turtledove) University of Pennsiylvania Press (1982)

B. Y. O. Uçkan, "Late Antique and Medieval Urban Texture of Olympos". Ed. M. Seyer, 40 Years of Excavations at Limyra. Akten des internationalen Symposions Wien, Wien, 3.-5. Dezember 2009 (2012) $241-248$.

B. Y. O. Uçkan, E. Öncü - Seçkin Evcim, "Olympos'un Roma ve Bizans Dönemi Kent Dokusu”. Ed. B. Yelda Olcay Uçkan, Olympos 12000 - 2014 Araştırma Sonuçları. AKMED, Antalya (2017) 9-30.

M. Whittow "Ruling the Late Roman and Early Byzantine City: A Continuous History". Past and Present 129 (1990) 3-29.

E. Zanini, "The Urban Ideal and Urban Planning in Byzantine New Cities of the Sixth Century A.D.". Eds. Luke Lavan - W. Bowden Theory and Practice in Late Antique Archeology. Brill Leiden - Boston (2003) 196-223. 